\title{
Review of the Molecular Genetics of Basal Cell Carcinoma; Inherited Susceptibility, Somatic Mutations, and Targeted Therapeutics
}

\author{
James M. Kilgour $\mathbb{D}$, Justin L. Jia and Kavita Y. Sarin *D \\ Department of Dermatology, Stanford University School of Medcine, Stanford, CA 94305, USA; \\ jkilgour@stanford.edu (J.M.K.); jljia@stanford.edu (J.L.J.) \\ * Correspondence: ksarin@stanford.edu
}

Citation: Kilgour, J.M.; Jia, J.L.; Sarin,

K.Y. Review of the Molecular

Genetics of Basal Cell Carcinoma;

Inherited Susceptibility, Somatic

Mutations, and Targeted

Therapeutics. Cancers 2021, 13, 3870.

https://doi.org/10.3390/

cancers 13153870

Academic Editor: David Wong

Received: 27 June 2021

Accepted: 29 July 2021

Published: 31 July 2021

Publisher's Note: MDPI stays neutral with regard to jurisdictional claims in published maps and institutional affiliations.

Copyright: (c) 2021 by the authors. Licensee MDPI, Basel, Switzerland. This article is an open access article distributed under the terms and conditions of the Creative Commons Attribution (CC BY) license (https:// creativecommons.org/licenses/by/ $4.0 /)$.
Simple Summary: Basal cell carcinoma is the most common human cancer worldwide. The molecular basis of BCC involves an interplay of inherited genetic susceptibility and somatic mutations, commonly induced by exposure to UV radiation. In this review, we outline the currently known germline and somatic mutations implicated in the pathogenesis of BCC with particular attention paid toward affected molecular pathways. We also discuss polymorphisms and associated phenotypic traits in addition to active areas of BCC research. We finally provide a brief overview of existing non-surgical treatments and emerging targeted therapeutics for BCC such as Hedgehog pathway inhibitors, immune modulators, and histone deacetylase inhibitors.

Abstract: Basal cell carcinoma (BCC) is a significant public health concern, with more than 3 million cases occurring each year in the United States, and with an increasing incidence. The molecular basis of BCC is complex, involving an interplay of inherited genetic susceptibility, including single nucleotide polymorphisms and genetic syndromes, and sporadic somatic mutations, often induced by carcinogenic exposure to UV radiation. This review outlines the currently known germline and somatic mutations implicated in the pathogenesis of BCC, including the key molecular pathways affected by these mutations, which drive oncogenesis. With advances in next generation sequencing and our understanding of the molecular genetics of BCC, established and emerging targeted therapeutics are offering new avenues for the non-surgical treatment of BCC. These agents, including Hedgehog pathway inhibitors, immune modulators, and histone deacetylase inhibitors, will also be discussed.

Keywords: basal cell carcinoma; skin neoplasms; dermatology; review; molecular genetics; germline mutation; somatic mutation; molecular targeted therapy

\section{Introduction}

Of all human cancers, basal cell carcinoma (BCC) is the most common worldwide, and in many countries, its incidence continues to increase, representing a significant public health burden [1]. Each year in the United States, more than 3 million cases occur, and one in five individuals in the U.S. are estimated to develop at least one BCC during their lifetime [2]. In addition to the potential morbidity of BCC, the cancer has a significant economic impact, with annual U.S. healthcare expenditure for these tumors reaching almost $\$ 4$ billion [3-5]. The molecular pathogenesis of BCC is complex, and involves an interplay of inherited genetic susceptibility [6] and sporadic somatic mutations [7]. The former predisposes an individual towards the development of BCC, and can include single nucleotide polymorphisms (SNPs), inherited disorders, and genetic traits [6], but the latter is generally required to induce carcinogenesis. While the types of variants that induce susceptibility to BCC are varied, the sporadic mutations often function to activate the Hedgehog $(\mathrm{HH})$ signaling pathway, a growth and development pathway integral to 
the pathogenesis of BCC. This review will discuss in more depth the currently known germline and somatic mutations implicated in the pathogenesis of BCC, as well as the underlying molecular pathways affected. We will also give an overview of established and emerging targeted, non-surgical, therapeutics which could revolutionize the treatment of this common and important skin cancer.

\section{Inherited Susceptibility to BCC}

Individuals can inherit an increased predisposition to BCC development, through genetic syndromes, germline SNPs and genetic traits [6]. Familial studies have been conducted to estimate the proportion of heritability of the keratinocyte-derived cancers (KC; i.e., BCC and squamous cell carcinoma). A study of 80,309 monozygotic and 123,382 dizygotic twins in Nordic countries reported a heritability of KC of $43 \%$ (95\% confidence interval (CI) 26-59\%) [8], while a study using data from the U.K. Biobank estimated that the heritability of BCC that could be explained by known inherited SNPs alone is $17 \%$ (95\% CI 7-27\%) [9].

\subsection{Genetic Syndromes Associated with BCC Development}

Some individuals face a much greater heritable risk of BCC than the general population, through inheritance of high penetrant germline mutations associated with one of 19 rare syndromes that have been linked to increased propensity of BCC. These syndromes, their associated mutations and molecular pathways, are outlined in Table 1 [6]. Research in the 1990s into the molecular basis of a rare genetic disorder known as Gorlin syndrome (also known as Nevoid Basal Cell Carcinoma syndrome) led to new understanding of the key oncogenic pathway underlying the etiology of BCC. Gorlin syndrome affects as many as 1 in 31,000 individuals in the U.K. [10], and is inherited through an autosomal dominant pattern with a high degree of penetrance but with variable phenotype [11]. Major clinical features of the syndrome include multiple, early-onset BCCs, jaw odontogenic keratocysts, palmar and plantar pits, and lamellar calcification of the falx cerebri [12]. BCCs present at a median age of 25, typically on sun exposed sites, and can range from few to thousands in number [13,14]. Interestingly, African American patients with Gorlin syndrome demonstrate less frequent development of BCC, reflecting the role of genetic factors such as pigmentation and epigenetic factors such as UV susceptibility in modulating carcinoma formation [14]. Similarly, SNPs in genes related to skin pigment, such as the melanocortin-1-receptor $(M C 1 R)$ gene, have been associated with earlier and more severe onset of BCC [13].

The most frequent mutations attributed to causing Gorlin syndrome are germline loss of function mutations affecting PTCH1 on chromosome 9q22.3 [15,16]. These inactivating mutations lead to premature termination of the $\mathrm{PTCH}$ protein, which is 7-transmembrane inhibitory receptor in the $\mathrm{HH}$ signaling pathway [17]. Interestingly, like the ocular cancer retinoblastoma, which similarly can be caused by inherited mutations in a recessive oncogene, a "two-hit hypothesis" has been proposed. This theory of carcinogenesis states that healthy cells require two separate mutagenic hits to produce carcinoma. Patients with inherited cancer syndromes, such as retinoblastoma and Gorlin, already have a preexisting germline mutation in one of their two copies of a tumor suppressor gene (i.e., PTCH1). This mutation alone is insufficient for cancer to occur. A second somatic mutation, as a result of UV radiation exposure for example, may subsequently induce malignancy through loss of the second copy of the tumor suppressor gene [18]. Other less commonly mutated genes implicated in Gorlin syndrome include PTCH2 and SUFU [15]. 
Table 1. Genetic syndromes associated with inherited susceptibility to BCC, with causative gene mutations and associated molecular pathways.

\begin{tabular}{|c|c|c|}
\hline Syndrome & Gene(s) & Gene Function(s) \\
\hline Gorlin syndrome & PTCH1, SUFU, PTCH2 & HH pathway members \\
\hline Bazex-Dupré-Christol syndrome & UBE2A, ACTRT1 & $\begin{array}{l}\text { DNA repair, Regulation of cell cycle, } \mathrm{HH} \\
\text { pathway }\end{array}$ \\
\hline Rombo syndrome & Unknown & Unknown \\
\hline $\begin{array}{l}\text { Generalized follicular basaloid } \\
\text { hamartoma syndrome }\end{array}$ & Unknown & Unknown \\
\hline Happle-Tinschert syndrome & Unknown & Unknown \\
\hline Muir-Torre syndrome & MSH2, MLH1, MSH6, PMS2 & DNA mismatch repair \\
\hline Brooke-Spiegler syndrome & $C Y L D$ & NF- $\kappa \beta$ and EGFR pathways regulator \\
\hline Cowden syndrome & PTEN & PI3K-AKT signaling pathway \\
\hline Cartilage-hair hypoplasia & $R M R P$ & Immune response \\
\hline Schimmelpenning syndrome & Unknown & Unknown \\
\hline Phacomatosis pigmentokeratotica & Unknown & Unknown \\
\hline Xeroderma pigmentosum & $X P A-X P G, X P V, P O L H$ & Nucleotide excision repair \\
\hline Bloom syndrome & $B L M(R E C O L 3)$ & Chromosomal stability \\
\hline Werner syndrome & WRN (RECOL2), LMNA & Chromosomal stability \\
\hline Rothmund-Thomson syndrome & REC0L4, C160rf57 & Chromosomal stability \\
\hline Schopf-Schulz-Passarge syndrome & WNT10A & $\begin{array}{l}\text { WNT/ } \beta \text {-catenin signaling pathway, cell } \\
\text { proliferation and migration }\end{array}$ \\
\hline Epidermodysplasia verruciformis & TMC6 (EVER1), TMC8 (EVER2) & $\begin{array}{l}\text { Immune response and signal transduction in } \\
\text { the endoplasmic reticulum }\end{array}$ \\
\hline Oculocutaneous albinism & $\begin{array}{c}\text { TYR, OCA2, TYRP1, SLC45A2 } \\
(M A T P), S L C 24 A 5, \text { C10orf11, 4q24 }\end{array}$ & Melanin synthesis \\
\hline Hermansky-Pudlak syndrome & HPS1-HPS8 & Melanin synthesis \\
\hline
\end{tabular}

Table adapted from Choquet et al. (2020) [6].

The Sonic HH signaling pathway is an embryologically conserved pathway that is vital for determining tissue patterning and cell fate during embryo development [19]. Within the skin, the $\mathrm{HH}$ pathway is responsible for stem cell maintenance and developmental control of the hair follicles and sebaceous glands [7]. HH signaling is activated when the $\mathrm{HH}$ ligand binds to a transmembrane receptor complex formed by the proteins PTCH and Smoothened (SMO). When not bound by the $\mathrm{HH}$ ligand, $\mathrm{PTCH}$ acts as a regulatory molecule, inhibiting translocation of SMO thereby reducing $\mathrm{HH}$ signaling. When $\mathrm{HH}$ ligand binds to $\mathrm{PTCH}$, the $\mathrm{HH}-\mathrm{PTCH}$ complex is degraded by lysosomes which de-represses SMO, upregulating the pathway's downstream signaling cascade via several proteins including suppressor of fused (SUFU). The ultimate result of this cascade is the release of members of the GLI protein family, which are ordinarily sequestered in the cytoplasm [7,19]. GLI acts as a transcription factor, which upon release can translocate to the cell nucleus and trigger transcription of genes involved in cell renewal, fate, and survival, as well as angiogenesis [7]. The normal functioning of the $\mathrm{HH}$ pathway is outlined in Figure 1. In Gorlin syndrome, germline inactivation of one copy of the PTCH1 gene followed by somatic loss of the second allele result in loss of SMO suppression and hence constitutive overexpression of the HH signal. The downstream effect is overproduction of the GLI1 transcription factor, which acts to drive BCC tumorigenesis $[18,20,21]$.

Bazex-Dupre-Christol syndrome is another genetic syndrome associated with the $\mathrm{HH}$ pathway and the development of multiple BCCs, alongside congenital hypotrichosis, 
follicular atrophoderma and milia [22]. It is inherited through an X-linked dominant pattern, with mutations in the ACTRT1 gene most commonly implicated. These mutations lead to premature truncation of the ARP-T1 protein, which normally functions as an inhibitor of the GLI1 transcription factor through function at the GLI1 gene promotor site. The mutation in ACTRT1 consequently results in enhanced GLI1-induced oncogenic transcription [23].

In addition to germline defects in the $\mathrm{HH}$ signaling pathway, BCC susceptibility may occur due to inherited deficiencies in DNA repair. Xeroderma Pigmentosum (XP) is autosomal recessive disorder caused by inherited mutations in any one of eight possible genes required for nucleotide excision repair (NER). NER is the process by which NER endonucleases repair segments of DNA containing pyrimidine dimers, the major signature of UV-induced DNA damage characterized by covalent bonding of adjacent thymine nucleotides. Without repair, the shape of the DNA strand becomes disrupted. Consequently, $X P$ patients have a significant UV-induced mutational burden, with strict lifelong avoidance of UV necessary for the prevention of skin cancer, including BCC, squamous cell carcinoma (SCC) and melanoma [24,25].

\subsection{Certain Inherited Phenotypic Traits Modulate BCC Susceptibility}

In addition to genetic disorders, certain inherited phenotypic traits have a demonstrated association with BCC risk. The traits associated with increased BCC formation are those pertaining principally to a fair skin phototype, and hence greater susceptibility to UV radiation-induced carcinogenesis. Individuals with fair skin, light-colored eyes and hair, childhood freckling, inability to tan and northern European ancestry are known to have increased rates of BCC development [26,27]. A meta-analysis of 29 studies by Khalesi et al. (2013) revealed that red hair, fair skin, and skin prone to burning and not tanning, is associated with a two-fold increased risk of BCC [28].

\subsection{Gene Polymorphisms Associated with Modulated BCC Risk}

Genome-wide association studies (GWAS) conducted in European populations in the U.S. and Iceland have identified 33 loci associated with BCC susceptibility [29-36]. Together, these 33 loci account for $10.98 \%$ of the heritability of BCC (Table 2). Many of these loci associated with altered BCC risk are shared with the other common KC, SCC [6]. Here, we will review in more depth the key biological pathways known to be implicated in BCC pathogenesis through the presence of gene polymorphisms.

\subsection{Gene polymorphisms Affecting pigmentary traits}

Traits associated with increased susceptibility to UV-damage, such as fair skin and light-colored eyes, are known to increase BCC risk. It is therefore not surprising that polymorphisms affecting genes involved in pigmentation modulate BCC predisposition. The melanocortin-1 receptor $(M C 1 R)$ gene is one example; it codes for a transmembrane, G-protein coupled receptor that activates adenylate cyclase to produce intracellular cAMP in response to stimulation by $\alpha$-melanocyte stimulating hormone ( $\alpha-\mathrm{MSH})$. Signaling through cAMP in turn induces maturation of phenomelanosomes into eumelanosomes, which are responsible for darker pigmentation and therefore increased UV resistance [37]. The MC1R gene is highly polymorphic within light skinned individuals [37], and studies of common variants have identified significantly increased risk of BCC with certain of these variants, even after controlling for skin phototype and hair color, suggesting that it may confer increased risk through mechanisms independent of pigmentation $[37,38]$. Han et al. (2006) conducted a nested case-control study, reporting that the 151 Cysteine variant specifically was associated with an adjusted odds ratio (OR) of 1.56 for BCC (95\% CI 1.03-2.34) [37]. Gudbjartsson et al. (2008) also identified polymorphisms within the TYR and ASIP pigmentation genes as significantly increasing BCC risk, with ORs of 1.14 $\left(p=6.1 \times 10^{-4}\right)$ and $1.35\left(p=1.2 \times 10^{-6}\right)$, respectively [39]. TYR encodes the enzyme tyrosinase, responsible for the production of melanin through the oxidation of tyrosine. ASIP 
codes for agouti signaling protein, which is an antagonist of the $\alpha$-MSH and melanocortin-1 receptor interaction, therefore functioning to suppress melanin production [39]. GWAS studies have further identified risk loci adjacent to other pigmentation genes, including IRF4, HERC2, LPP, BNC2, EXOC2, RALY and SLC45A2, as being significant for BCC. While most of these loci are associated with increased risk, SLC45A2, BNC2 and HERC2 were all reported as having ORs of less than one, supporting decreased risk [29].

Table 2. Genome-wide significant single nucleotide polymorphisms associated with modulated BCC risk.

\begin{tabular}{|c|c|c|c|c|c|c|}
\hline SNP & $\begin{array}{c}\text { Region of } \\
\text { Chromosome }\end{array}$ & Locus & $\begin{array}{c}\text { Alleles } \\
\text { (Major/Minor) }\end{array}$ & $\begin{array}{l}\text { Minor Allele } \\
\text { Frequency }\end{array}$ & Odds Ratio & $p$-Value \\
\hline rs57142672 & $1 \mathrm{p} 36$ & RCC2 & $\mathrm{A} / \mathrm{G}$ & 0.34 & 1.13 & $1.0 \times 10^{-23}$ \\
\hline rs61824911 & $1 q 42$ & RHOU & $\mathrm{A} / \mathrm{G}$ & 0.28 & 1.11 & $1.1 \times 10^{-14}$ \\
\hline rs57244888 & $2 \mathrm{p} 24$ & $M Y C N$ & $\mathrm{~T} / \mathrm{C}$ & 0.12 & 0.76 & $4.7 \times 10^{-12}$ \\
\hline rs2080303 & $2 q 33$ & $A L S 2 C R 12$ & $\mathrm{C} / \mathrm{T}$ & 0.32 & 1.13 & $7.4 \times 10^{-19}$ \\
\hline rs2116709 & $3 p 13$ & FOXP1 & $\mathrm{A} / \mathrm{T}$ & 0.40 & 0.90 & $2.3 \times 10^{-17}$ \\
\hline rs191177147 & $3 q 28$ & $L P P$ & $\mathrm{G} / \mathrm{T}$ & 0.39 & 1.11 & $1.2 \times 10^{-14}$ \\
\hline rs35407 & $5 p 13$ & $S L C 45 A 2$ & $\mathrm{G} / \mathrm{A}$ & 0.04 & 0.63 & $5.2 \times 10^{-27}$ \\
\hline rs421284 & $5 p 15$ & CLPTM1L & $\mathrm{T} / \mathrm{C}$ & 0.44 & 0.90 & $1.1 \times 10^{-18}$ \\
\hline rs1050529 & $6 p 21.33$ & $H L A-B$ & $\mathrm{C} / \mathrm{T}$ & 0.25 & 0.90 & $2.6 \times 10^{-9}$ \\
\hline rs9267650 & $6 p 21.33$ & NEU1 & $\mathrm{A} / \mathrm{T}$ & 0.05 & 1.17 & $1.1 \times 10^{-8}$ \\
\hline rs9275642 & $6 \mathrm{p} 21.32$ & HLA-DQA2 & $\mathrm{C} / \mathrm{T}$ & 0.21 & 0.89 & $2.4 \times 10^{-12}$ \\
\hline rs2294214 & $6 \mathrm{p} 22$ & CASC15 & $\mathrm{A} / \mathrm{C}$ & 0.32 & 1.07 & $3.1 \times 10^{-8}$ \\
\hline rs12203592 & $6 \mathrm{p} 25.3$ & IRF4 & $\mathrm{C} / \mathrm{T}$ & 0.17 & 1.48 & $2.4 \times 10^{-152}$ \\
\hline rs12210050 & $6 p 25.3$ & EXOC2 & $\mathrm{C} / \mathrm{T}$ & 0.17 & 1.25 & $1.0 \times 10^{-51}$ \\
\hline rs4710154 & $6 q 27$ & MIR3939 & $\mathrm{A} / \mathrm{T}$ & 0.32 & 1.08 & $1.1 \times 10^{-8}$ \\
\hline rs7776701 & $7 \mathrm{p} 12$ & TNS3 & $\mathrm{C} / \mathrm{T}$ & 0.48 & 0.94 & $4.2 \times 10^{-8}$ \\
\hline rs73183643 & $7 q 22$ & CUX1 & $\mathrm{G} / \mathrm{A}$ & 0.24 & 0.90 & $1.5 \times 10^{-13}$ \\
\hline rs157935 & $7 q 32$ & KLF14 & $\mathrm{T} / \mathrm{G}$ & 0.29 & 0.81 & $8.5 \times 10^{-11}$ \\
\hline rs10093547 & $8 q 21.11$ & ZFHX4 & $\mathrm{T} / \mathrm{G}$ & 0.06 & 0.82 & $4.6 \times 10^{-15}$ \\
\hline rs11993814 & $8 q 21.13$ & ZВТВ10 & $\mathrm{C} / \mathrm{T}$ & 0.26 & 0.92 & $8.8 \times 10^{-11}$ \\
\hline rs141115006 & $8 q 22$ & RGS22 & $\mathrm{C} / \mathrm{T}$ & 0.17 & 0.88 & $2.0 \times 10^{-15}$ \\
\hline rs7874604 & 9 p21 & $C D K N 2 B-A S 1$ & $\mathrm{~T} / \mathrm{C}$ & 0.46 & 0.91 & $4.5 \times 10^{-13}$ \\
\hline rs10810657 & 9 p22 & BNC2 & $\mathrm{A} / \mathrm{T}$ & 0.41 & 0.90 & $1.5 \times 10^{-17}$ \\
\hline rs73635312 & $10 \mathrm{p} 14$ & GATA3 & $\mathrm{G} / \mathrm{A}$ & 0.14 & 0.84 & $2.8 \times 10^{-23}$ \\
\hline rs7907606 & $10 \mathrm{q} 24$ & OBFC1 & $\mathrm{T} / \mathrm{G}$ & 0.17 & 1.10 & $4.7 \times 10^{-9}$ \\
\hline rs1126809 & $11 \mathrm{q} 14$ & $T Y R$ & $\mathrm{G} / \mathrm{A}$ & 0.28 & 1.12 & $2.5 \times 10^{-19}$ \\
\hline rs11170164 & $12 q 13$ & KRT5 & $\mathrm{C} / \mathrm{T}$ & 0.08 & 1.19 & $1.1 \times 10^{-15}$ \\
\hline rs7335046 & $13 q 32$ & UBAC2 & $\mathrm{C} / \mathrm{G}$ & 0.12 & 1.26 & $2.9 \times 10^{-8}$ \\
\hline 2916300 & $15 q 13$ & OCA2/HERC2 & $\mathrm{T} / \mathrm{C}$ & 0.29 & 0.87 & $8.2 \times 10^{-17}$ \\
\hline rs1805007 & $16 q 24$ & $M C 1 R$ & $\mathrm{C} / \mathrm{T}$ & 0.07 & 1.40 & $2.5 \times 10^{-63}$ \\
\hline rs78378222 & $17 \mathrm{p} 13$ & TP53 & $\mathrm{T} / \mathrm{G}$ & 0.01 & 1.41 & $1.8 \times 10^{-10}$ \\
\hline rs10425559 & 19 p13 & PLIN3 & $\mathrm{G} / \mathrm{A}$ & 0.40 & 0.93 & $2.8 \times 10^{-8}$ \\
\hline rs214785 & 20 p13 & TGM3 & $\mathrm{T} / \mathrm{C}$ & 0.18 & 1.19 & $7.9 \times 10^{-33}$ \\
\hline rs6059655 & $20 q 11$ & RALY & $\mathrm{G} / \mathrm{A}$ & 0.07 & 1.24 & $2.5 \times 10^{-26}$ \\
\hline rs2776353 & $21 q 22$ & LINC00111 & $\mathrm{A} / \mathrm{T}$ & 0.33 & 0.91 & $1.6 \times 10^{-12}$ \\
\hline
\end{tabular}




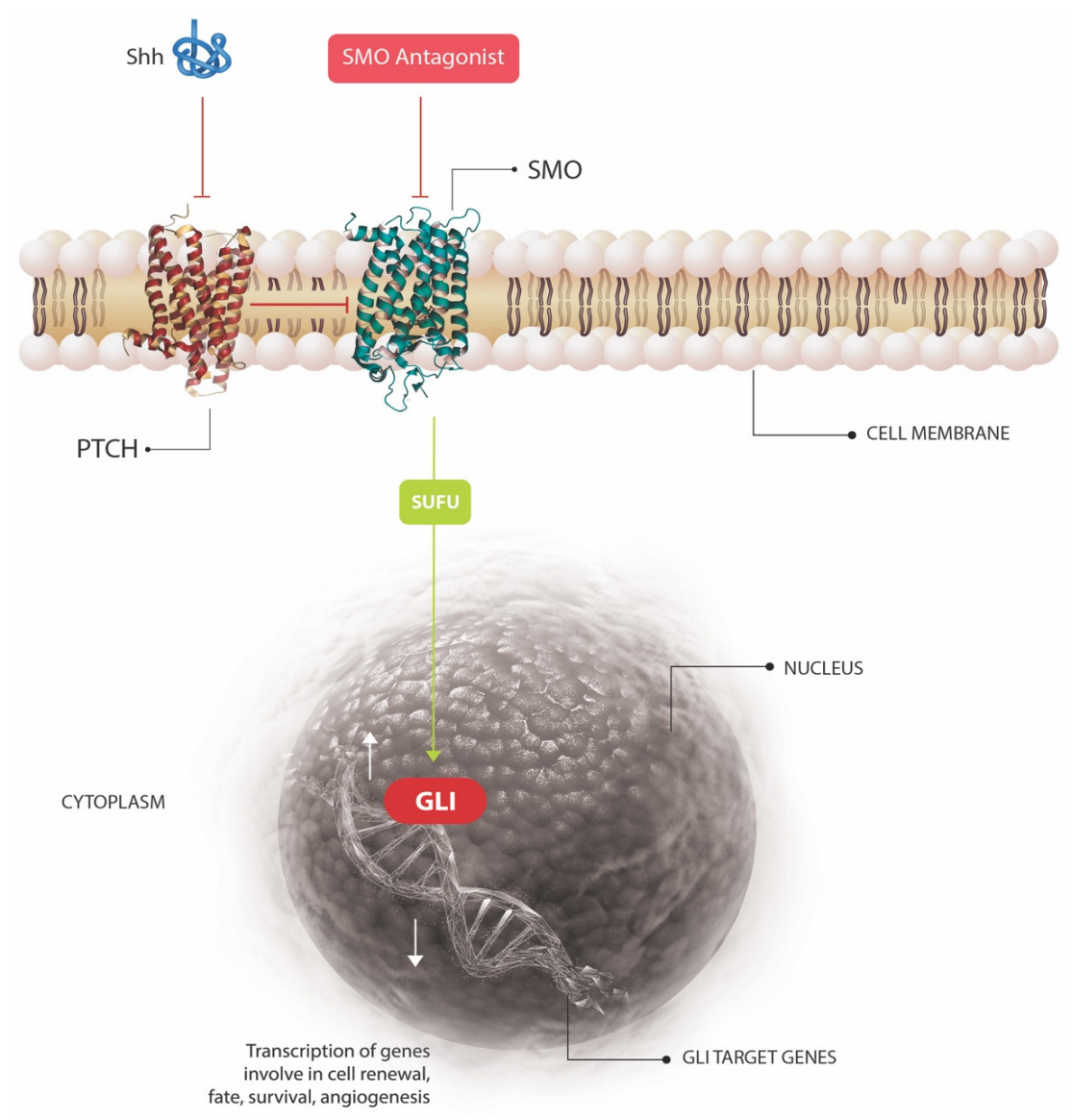

Figure 1. Overview of the Sonic Hedgehog signaling pathway. The HH ligand binds to a transmembrane receptor complex formed by the proteins PTCH and Smoothened (SMO). When not bound by the $\mathrm{HH}$ ligand, $\mathrm{PTCH}$ acts as a regulatory molecule, inhibiting translocation of SMO cilia thereby reducing $\mathrm{HH}$ signaling. When $\mathrm{HH}$ ligand binds to $\mathrm{PTCH}$, the $\mathrm{HH}-\mathrm{PTCH}$ complex is degraded by lysosomes which de-represses $\mathrm{SMO}$, upregulating the pathway's downstream signaling cascade via several proteins including suppressor of fused (SUFU). This ultimately results in release of members of the GLI protein family, such as GLI1, which are ordinarily sequestered in the cytoplasm [7,19]. GLI1 acts as a transcription factor, which upon release can translocate to the cell nucleus and trigger transcription of genes involved in cell renewal, fate, and survival, as well as angiogenesis [7].

\subsection{Gene Polymorphisms Affecting Tumor Suppressor Proteins}

A polymorphism, rs78378222, in TP53, which encodes the tumor suppressor TP53 gene, is highly significant for BCC, with an overall OR of $2.16\left(95 \%\right.$ CI 1.83-2.54; $\left.p=2.2 \times 10^{-20}\right)$. P53 can suppress tumor formation through enhancing the function of the protein p21, an inhibitor of the cell cycle regulator, cyclin D kinase. P53 also enhances apoptosis, via inhibition of BCL2, an anti-apoptotic protein [40], and also suppresses the $\mathrm{HH}$ pathway protein SMO [7]. The rs78378222 polymorphism affects the AATAAA polyadenylation signal of the $3^{\prime}$ untranslated region of the TP53 gene, changing it to AATACA. This results in an impaired poly-adenine tail of the TP53 mRNA, which is necessary for stabilization and nuclear export [35]. Another important group of tumor suppressor genes are the cyclin D kinase inhibitor genes, CDKN2A and CDKN2B, which regulate the cell cycle. Stacey et al. (2009) identified that the rs 2151280 polymorphism at the $9 \mathrm{p} 21$ loci near these genes is associated was an OR of $1.19\left(95 \%\right.$ CI 1.12-1.26; $\left.p=6.9 \times 10^{-9}\right)$ for BCC [36].

\subsection{Gene Polymorphisms Affecting Epidermal Differentiation and Cytoskeleton Organization}

Genes determining epidermal differentiation and cytoskeleton organization have also been identified as harboring polymorphisms associated with increased BCC susceptibility. The KRT5 gene produces the protein K5, which along with its heterodimeric partner K14, 
form the major keratins of the intermediate filament cytoskeletal network within basal keratinocytes. This network is vital for the basal layer's structural integrity. The rs11170164 polymorphism results in a G138E substitution in the KRT5 gene, resulting in an increased risk of BCC (OR 1.35; 95\% CI 1.23-1.50; $\left.p=2.1 \times 10^{-9}\right)$ [36]. Stacey et al. (2008) further identified the $1 \mathrm{p} 36$ and $1 \mathrm{q} 42$ loci as being risk-conferring for $\mathrm{BCC}$, both of which contain genes involved in regulation of the cytoskeleton and keratinocyte differentiation [31].

\subsection{Gene Polymorphisms Affecting NOTCH Signaling}

The NOTCH signaling pathway has an important role in the regulation of keratinocyte proliferation and differentiation, and aberrant signaling through the pathway is known to be associated with cutaneous abnormalities and skin cancer [41]. In experiments of human nodular BCCs, NOTCH signaling has been shown to be depressed, and when treated with a Notch signaling peptide, increased apoptosis of BCC cells was revealed [42]. NOTCH signaling regulates epidermal development through a multitude of means and is complex (Figure 2). P53 is believed to induce NOTCH signaling, which in turn suppresses AP-1 (an p53 inhibitor), further promoting NOTCH. NOTCH signaling down regulates keratinocyte proliferation through two mechanisms: firstly, via inhibiting p63, a transcription factor necessary for epidermal growth, and secondly, via enhancing the expression of CDKN1A, a cell-cycle inhibitor. NOTCH signaling also regulates keratinocyte differentiation, through enhancing expression of transcription regulators such as IRF6 and the Hes/Hey genes, as well as promoting signaling through the retinoic acid pathway via increased expression of various retinol-binding proteins [41]. Polymorphisms in regions of transcription factor genes (FOXP1 and IRF4) which repress the NOTCH pathway have been implicated in increased propensity to BCC. The rs 2116709 polymorphism of FOXP1 is protective against BCC, with an OR of $0.90\left(p=2.3 \times 10^{-17}\right)$, while the rs12203592 variant of IRF4 results in an increased risk of BCC (OR 1.48; $\left.p=2.4 \times 10^{-152}\right)$ [29].

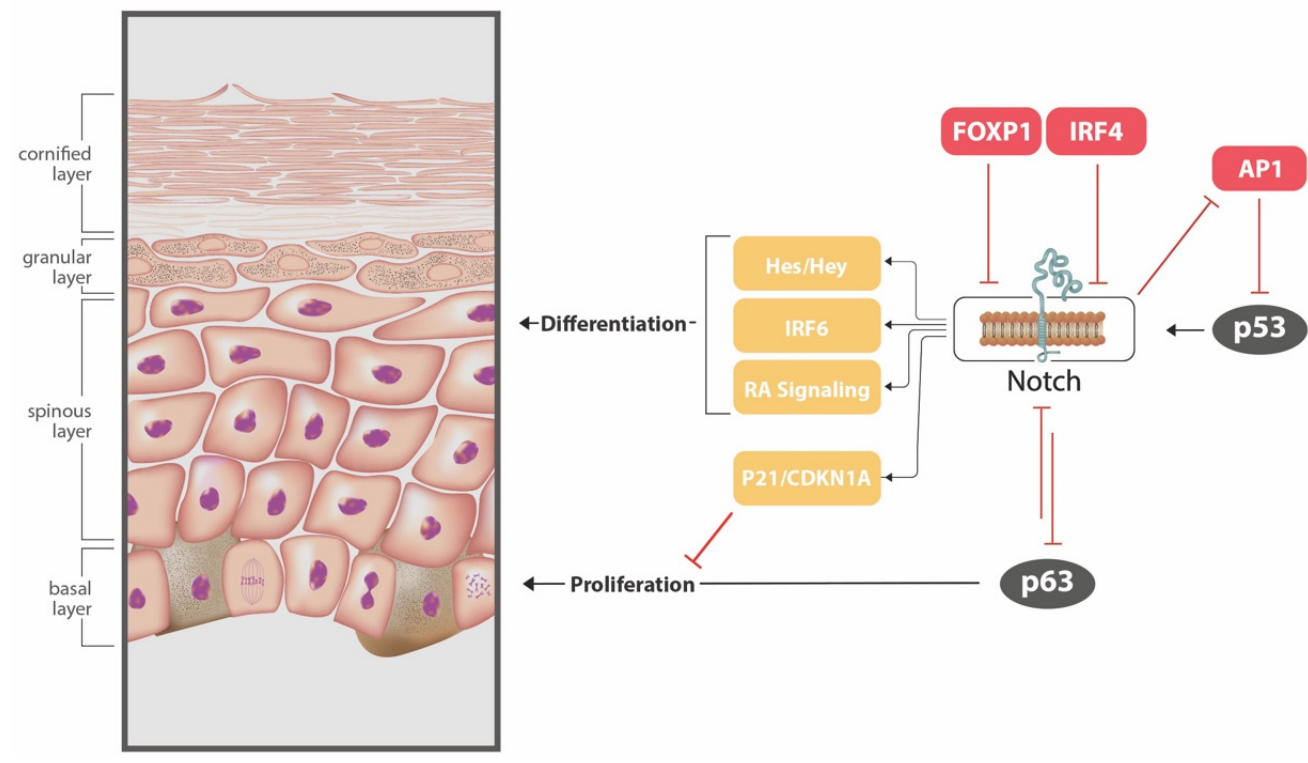

Figure 2. Downstream regulatory effects of $\mathrm{NOTCH}$ signaling on keratinocyte proliferation and differentiation. $\mathrm{P} 53$ induces NOTCH signaling though binding of a promotor region. Activation of the NOTCH signaling pathway involves proteolytic cleavage of the NOTCH intracellular domain, which is able to suppress AP-1 (a P53 inhibitor) further promoting NOTCH signaling. NOTCH down regulates keratinocyte proliferation through inhibition of p63, a transcription factor necessary for epidermal growth, and via enhancing expression of CDKN1A. NOTCH signaling regulates keratinocyte differentiation, through enhancing expression of transcription regulators (IRF6 and the Hes/Hey genes), as well as promoting signaling through the retinoic acid pathway. FOXP1 and IRF4 play a regulatory role in NOTCH signaling, both having a repressive function. 


\subsection{Gene Polymorphisms Affecting Telomere Maintenance}

Instability of chromosomes is a known risk factor for $\mathrm{KC}$, including $\mathrm{BCC}$, as evidenced by predisposition to $\mathrm{BCC}$ as a feature of several inherited genetic disorders characterized by diminished chromosomal stability (Table 1) [6]. Chromosomal instability is believed to contribute to cancer pathogenesis through genetic variation that increases tumor adaptations that augment tumor survival [43]. Further, polymorphisms in genes related to telomere maintenance have been identified in several studies as associated with BCC risk. This includes variants affecting the gene TERT, which codes for the enzyme telomerase which adds protective repeat sequences to telomeres [33,36], and the gene OBFC1, a telomere-length regulating gene [29]. Increasing telomere length immortalizes cells, preventing senescence and permitting excessive cell replication, a feature of $90 \%$ of solid malignancies [44].

\subsection{Gene Polymorphisms Affecting DNA Repair}

UV radiation-induced DNA damage is a key carcinogenic mechanism in the pathogenesis of BCC, and the capacity for DNA repair genes to rectify this damage is important in preventing malignancy. Lin et al. studied SNPs across 165 DNA repair pathway genes, identifying variants within three key repair genes, XPA, MUS81 and NABP2, which are all associated with significantly modulated risk of $B C C$. The former was reported to decrease propensity to BCC (OR 0.93), while the latter two increase the risk (ORs 1.06 and 1.11, respectively) [45].

\subsection{Gene Polymorphisms Affecting Cutaneous Immunity}

Cutaneous immunity and inflammation are known to modulate the risk of skin cancers, including BCC. Individuals with immunosuppression, such as those receiving solid organ transplants are known to suffer with a high burden of cutaneous malignancies, in part due to the loss of immune regulation and its anti-cancer effect. Polymorphisms within the human leukocyte antigen (HLA) region have been associated with altered BCC susceptibility, in addition to IRF4 which has a role in immune regulation, and $U B A C 2$, which is involved in inflammation [6]. Welsh et al. (2009) further studied the CT60 GG genotype of the cytotoxic lymphocyte-associated antigen-4 (CTLA-4) gene in a population-based cohort study of white individuals in New Hampshire. They reported that individuals with the CT60 GG genotype had decreased risk of BCC (OR 0.7; 95\% CI 0.5-0.9). CTLA-4 plays an instrumental role in UV radiation-induced cutaneous immunosuppression, as it is expressed on t-regulatory cells that are up regulated by UV. CTLA- 4 on t-regulatory cells interacts with antigen-presenting cells, suppressing t-lymphocyte activation and neutralizing the anti-tumor effect of effector t-lymphocytes. The CT60 GG genotype results in reduced t-regulatory cell function, and hence diminished UV-induced immunosuppression and ultimately augmented anti-tumor capacity. At the same time, individuals with this genotype are at amplified risk of multiple autoimmune diseases [46].

\subsection{Gene Polymorphisms Associated with a Truncal, Clustering BCC Phenotype}

In addition to modulating BCC risk, gene polymorphisms have also been associated with distinct phenotypes of BCC. One such phenotype is a constellation of younger male patients with clusters of multiple BCCs affecting non-sun exposed truncal skin [47]. This phenotype has been linked to germline polymorphisms of genes coding for the hepatic detoxification enzymes cytochrome p450 2D6 and glutathione s-transferase [48-50], as well as of the vitamin D receptor [50], and TNF- $\alpha[50,51]$.

\section{Somatic Mutations Implicated in BCC Tumorigenesis}

While germline polymorphisms result in an inherited predisposition to BCC, subsequent sporadic somatic mutations are required before cancer develops. Genomic analysis has found that BCC tumors are the most mutated of any human cancer, with on average 65 mutations per megabase [52], and the common cancer-related genes mutated in BCC 
are illustrated in Figure 3. The primary driver of the great mutational burden in BCC, and therefore the primary environmental risk factor, is exposure to UV radiation [53]. Ninety percent of single-nucleotide variants in a genomic analysis study were identified as mutations characteristic of UV-induced DNA damage (known as UV signature mutations), which is greater than that of other cutaneous malignancies such as melanoma [52].

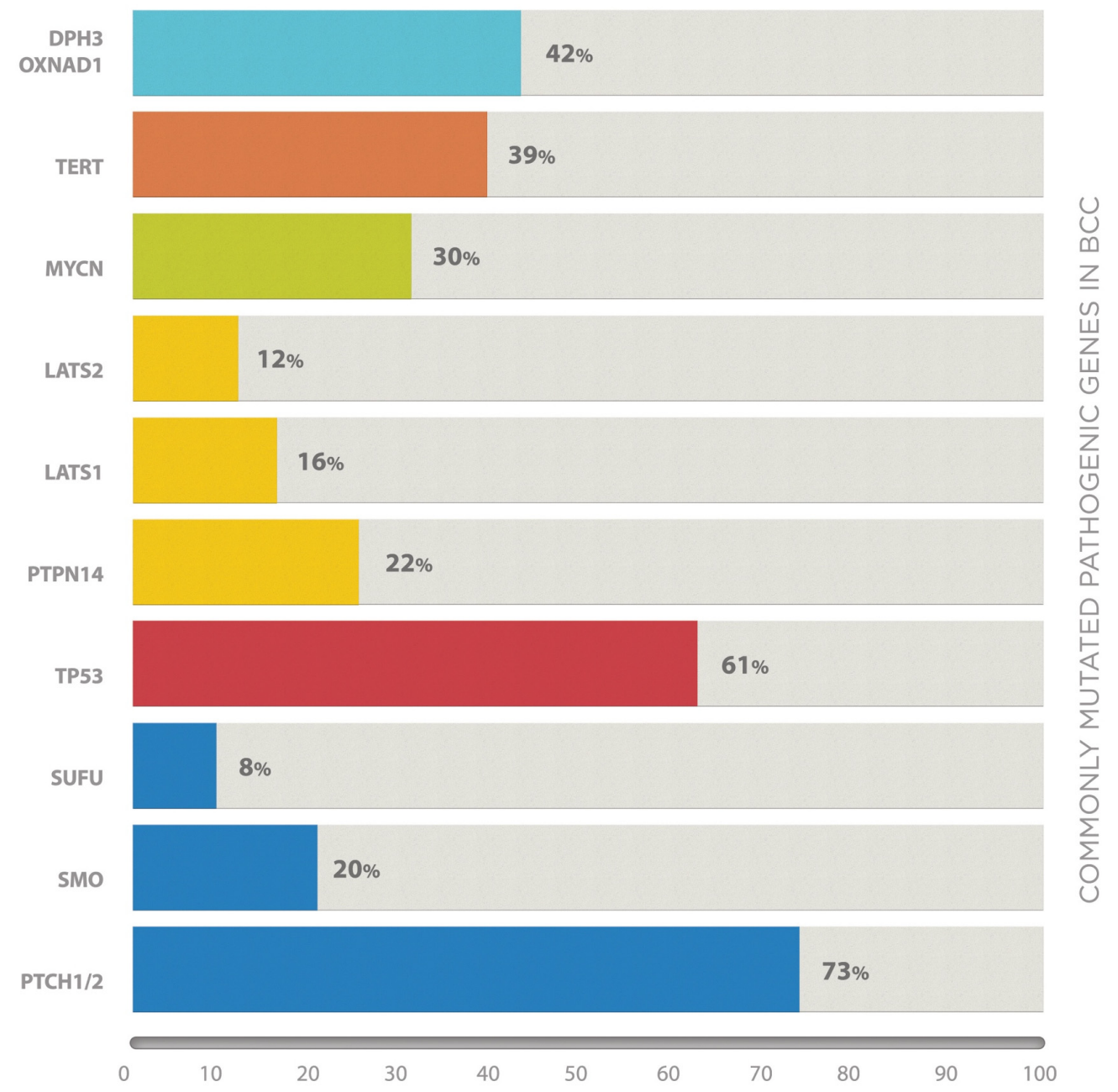

PERCENTAGE OF BCC TUMORS HARBORING SOMATIC MUTATIONS IN GENE

\section{Hippo-Yap $\quad$ HH Pathway}

Figure 3. Cancer-related genes commonly affected by somatic mutations in BCC. Bar chart illustrates the common cancer-related genes in BCC affected by somatic mutations, with the percent of BCC tumors harboring such mutations as reported in genetic analysis studies. Genes are grouped by their respective molecular pathway, with genes coding for proteins in the $\mathrm{HH}$ pathway illustrated in blue, and the Hippo-Yap pathway in yellow. Percentages are taken from the studies with the largest sample size to date.

In particular, UV radiation is able to induce carcinogenesis in a multifaceted manner, through direct DNA damage, particularly involving oncogenes and tumor suppressor genes such as PTCH1 and $p 53$ as previously discussed, suppression of cutaneous immunity and skin inflammation [6]. UVB is known to be highly mutagenic, as UVB is directly absorbed by DNA strands, resulting in UV signature mutations [54]. The two commonly identified DNA photoproducts generated primarily by UVB radiation absorption are cyclobutane pyrimidine dimers (CPDs) and 6-pyrimidine-4-pyrimidone (6-4 PPs) photo- 
products (Figure 4). Both photoproducts cause disruption in the shape of the DNA strand, by distorting the strand's backbone. Consequently, DNA transcription and replication by polymerases is interrupted, as these lesions act as stop points for the polymerases. Without repair, these lesions will induce UV signature mutations, defined as cytosine $(C)$ to guanine (G) base substitutions and CC to GG tandem mutations. In addition to UVB, UVA may also be able to directly produce CPDs [54].
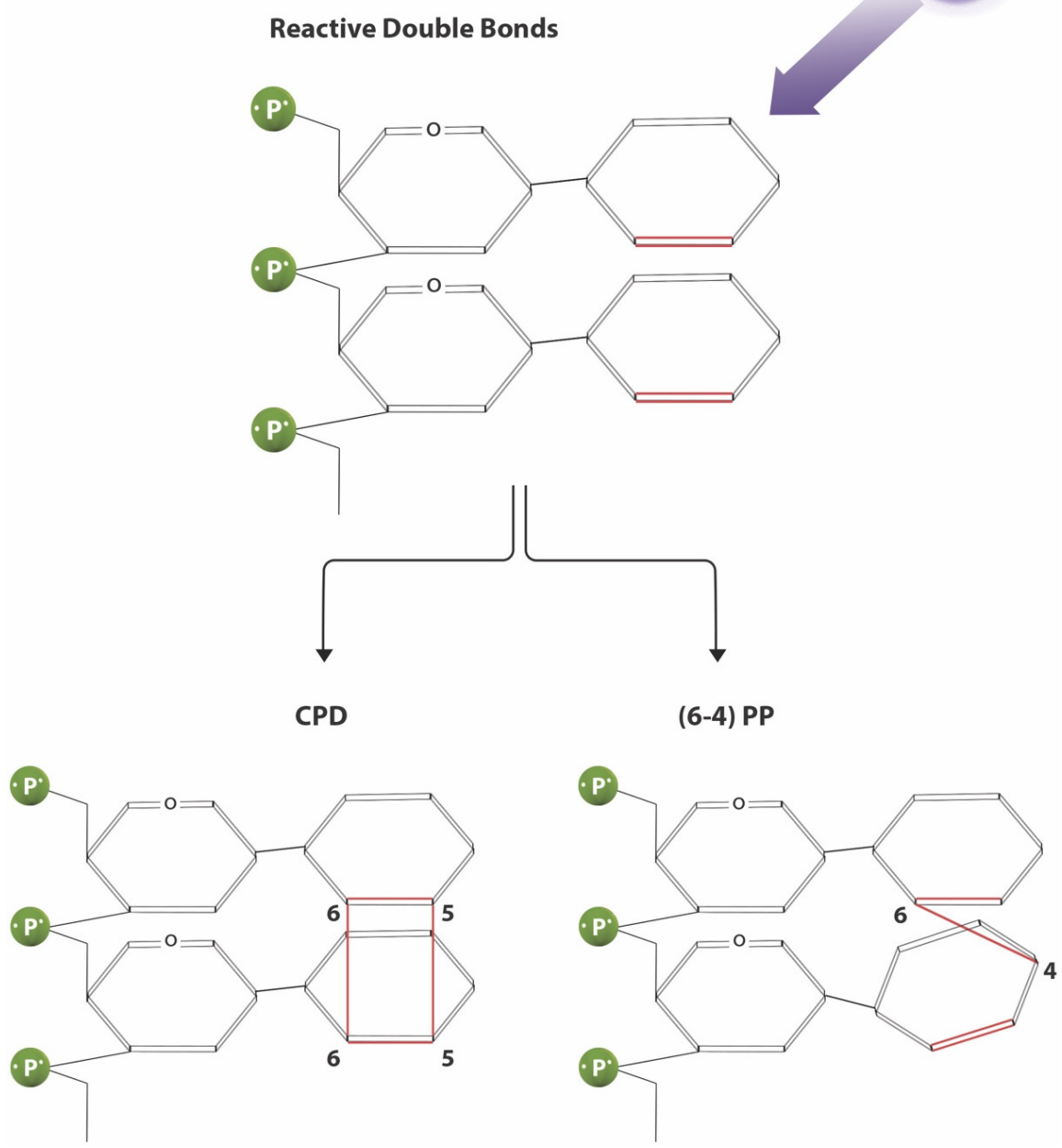

Figure 4. Photoproducts of direct UV-induced DNA damage. Absorption of UV radiation (principally UVB) by DNA strands result in the formation of photoproducts which disrupt the strand's backbone, resulting in interruption of transcription and replication and the development of UV signature mutations. Cyclobutane pyrimidine dimers (CPDs) are characterized by formation of a cyclobutane ring by two adjacent thymine or cytosine bases. 6-pyrimidine-4-pyrimidone (6-4 PPs) photoproducts are formed by a single bond between the 6 carbon of the $5^{\prime}$ pyrimidine base and the 4 carbon of the $3^{\prime}$ pyrimidine base.

\subsection{Frequent Somatic Mutations Identified in BCC: The HH Pathway}

At least $90 \%$ of BCCs show enhanced signaling through the $\mathrm{HH}$ pathway through somatic loss of functions mutations in the PTCH1 gene and activating mutations of SMO. The downstream consequence of these mutations is activation of the transcription factor GLI1 (Figure 1). The frequency of somatic PTCH1 mutations in BCC studies is as high as $75 \%$ [7], and the mutations are typically non-synonymous, nonsense and splice site mutations found throughout the length of the gene. Supporting the important causative 
role of UV in BCC pathogenesis, $50 \%$ of $\mathrm{PTCH} 1$ mutations are UV-signature in nature [7]. Activating mutations of SMO are similarly reported in 10-20\% of BCCs [52], while less common $\mathrm{HH}$ pathway mutations include loss of function variants of SUFU (approximately $8 \%$ of BCCs) [52] and mutations in the PTCH1-homologue PTCH2 [55].

\subsection{TP53}

The role of the essential tumor suppressor protein p53, coded for by the TP53 gene, was outlined in our discussion of common germline polymorphisms associated with inherited susceptibility to BCC. Somatic mutations in TP53 are frequent in all human cancers, and in BCC, non-synonymous mutations occur sporadically in approximately $61 \%$ of cases [7,52], with hotspots identified at codons 177, 196 and 245 [56,57]. Similarly to PTCH1, the majority of mutations in TP53 in BCC are UV-signature [7].

\subsection{The Hippo-Yap Signaling Pathway}

The Hippo pathway is essential in tissue growth restriction, comprising of a cascade of kinases that use phosphorylation to suppress a downstream transcriptional co-activator, Yes-associated protein (YAP) [7]. Dysfunctional regulation of this pathway has been reported in BCC from RNA sequencing studies, with up-regulated YAP triggering basal keratinocyte proliferation [58]. Premature stop mutations of the LATS1 gene, coding for one of the kinases in the Hippo pathway, have been reported in $16 \%$ of BCCs, and similarly, $23 \%$ of BCCs contain loss of function mutations in the PTPN14 gene, a tumor suppressor functioning as a negative regulator of YAP. Furthermore, $12 \%$ of tumors may contain mutations in the LATS2 gene, an analogue of LATS1 [52].

\subsection{MYCN/FBXW7 Signaling}

$M Y C N$ is a transcriptional activator likely downstream of the HH pathway and therefore involved in cell proliferation and differentiation [55]. 30\% of BCCs have demonstrated missense mutations, mostly within the MYC box 1 domain that interacts with the tumor suppressor FBXW7 [52]. FBXW7 functions to trigger N-MYC ubiquitin degradation [59], and mutations in the box 1 domain prevents the MYCN/FBXW7 interaction necessary for this to occur [52].

\subsection{TERT}

The role of telomerase, the product of the TERT gene, for immortalization of cancer cells was previously discussed. UV-signature mutations affecting the promoter region of the TERT gene are commonly reported in BCC, present in 39-74\% [7].

\subsection{DPH3-OXNAD1 Bidirectional Promotor}

The bidirectional promotor of the DPH3 and OXNAD1 genes has been identified as a common site for somatic mutations in BCC, with UV-signature mutations present in $42 \%$ of tumors [60]. The DPH3 gene is necessary to produce diphthamide, a modified histidine residue present in eukaryotic elongation factor 2 , itself needed for protein synthesis. Inactivation of DPH3 is characterized by loss of a tumor cell's metastatic ability, and therefore the gene has a tumor suppressor activity [61].

\subsection{Other Putative Driver Genes}

Other driver genes that have been proposed as pathogenic of BCC include PPP6C, a gene involved in the regulation of cyclin D1 and therefore cell cycle progression, and STK19, a kinase of unknown function which may be involved in transcriptional regulation [7,61]. Bonilla et al. (2016) have also implicated mutations in the mitogen-associated protein kinase (MAPK) growth pathway, reporting gain of function mutations in the KRAS, NRAS, HRAS and PIK3CA genes, collectively occurring in $4 \%$ of genotyped BCCs, in addition to $4 \%$ of BCCs demonstrating mutations in ERBB2 [52]. Additional genes with identified mutations in BCCs at lower frequency include RB1, KNSTRN, ARID1A, CASP8, RAC1 [52], 
CSMD1/2, GRIN2A, PREX2 [53], and NOTCH1/2 [52,53]. It is unclear if these genes serve as primary drivers or may represent secondary mutations in BCC development.

\section{Targeted Therapeutics for BCC}

Through this review, we have discussed our current understanding of the molecular genetics of BCC, which has been enhanced greatly through the development over the past decade of next generation sequencing technologies. While at present, surgical excision remains the gold standard therapy for BCC, alongside destructive modalities (i.e., 5fluorouracil, imiquimod, photodynamic therapy and electrodesiccation and curettage), we are now entering a new era of molecularly targeted therapeutics, which function by modulating key molecular pathways integral to BCC pathogenesis [62].

\subsection{HH Pathway Inhibitors}

The first molecularly targeted therapeutic for BCC was the SMO inhibitor cyclopamine (see Figure 1 for site of action), but serious side effects include weight loss and death in murine models made it an nonviable therapeutic option [63]. Further drug development, however, led to the formulation of vismodegib and sonidegib, oral SMO antagonists with tolerable side effect profiles, both of which are FDA approved for the treatment of locally advanced or metastatic BCCs unsuitable for surgical excision or radiotherapy [62]. In the largest randomized controlled-trial (RCT) to date of vismodegib, STEVIE, 1215 patients with $\mathrm{BCC}$ were treated with $150 \mathrm{mg}$ once daily. The overall response rate (ORR) according to the RECIST 1.1 criteria was reported as $68.5 \%$ for locally advanced BCC, and $36.9 \%$ for metastatic BCC. $31 \%$ of patients, however, were unable to complete treatment due to the adverse event profile, which included muscle spasms from increase intracellular calcium, alopecia from $\mathrm{HH}$ inhibition which is necessary for hair follicle cycling, loss of sense of taste, fatigue and weight loss [64]. An RCT of sonidegib revealed similar efficacy and adverse event profile in patients with locally advanced BCC [65]. An important issue with both of these agents, however, is the risk of resistance through acquired mutations in SMO [62]. Given the high discontinuation rates of oral SMO antagonists, a topical inhibitor, patidegib, has also been trialed with reduced disease burden in patients with Gorlin syndrome [66]. The anti-fungal agent itraconazole is additionally known to function as a weak HH pathway inhibitor, and has been suggested as a potential therapy for BCC. Early trials, however, of oral and topical itraconazole have shown mixed results [67].

\subsection{Immune Modulators}

Another potential target for BCC treatment is immunotherapy, given the anti-tumor effect of cutaneous immune cells. Cemiplimab is a monoclonal antibody which functions as an inhibitor of programmed cell death receptor 1 (PD-1), which is an immune checkpoint receptor located on lymphocytes. Upon activation by the PD-1 ligand, the checkpoint triggers down regulation of immune function and therefore immune tolerance. The PD-1 ligand has been found to be expressed on BCC cells [68], and cemiplimab has demonstrated efficacy in locally advanced and metastatic BCC [69]. Other PD-1 inhibitors, such as pembrolizumab, are also under investigation, with a proof-of-principle study of 16 patients with advanced BCCs, demonstrating an overall response rate per RECIST 1.1 of $38 \%$ after 18 weeks [70].

\subsection{Emerging Therapeutics}

Experimental therapies for BCC using novel paradigms are emerging. These include small molecular antagonists of the transcription factor downstream of the $\mathrm{HH}$ pathway, GLI1, which may be able to avoid the issues of resistance experienced by inhibitors acting upstream. Verteporfin is one such agent under investigation [7]. Intratumor injection of a DNAzyme targeting the mRNA of the transcription factor c-JUN, is another novel therapy that has been tested in a phase 1 study of nine patients in Australia. c-JUN expression is regulated by GLI1 and is highly expressed in BCC cells compared to normal tissue. In 
the trial, the agent was able to reduce c-JUN levels in all nine tumors and decrease the histological depth of five [71]. Lastly, histone deacetylase (HDAC) inhibitors may have promise in BCC, potentially through sequestering GLI to the inner nuclear membrane [72]. A phase 2 open label single arm trial of the topical HDAC inhibitor, remetinostat, demonstrated an ORR of $69.7 \%$ in 33 per-protocol tumors, alongside pathological clearance rates of $54.8 \%$ (manuscript in press; ClinicalTrials.gov Identifier NCT03180528). Acetylation of GLI1 at the K518 locus has been shown to cause sequestration of the transcription factor inside the inner nuclear membrane, preventing its release and its associated pro-oncogenic downstream activity. HDAC isoform 1 inhibitors increase GLI1 acetylation and through this mechanism likely suppress tumor growth [73].

\subsection{Metastasis}

Although locally destructive, BCC metastasis is exceedingly rare with an estimated frequency ranging from 1 in 1000 to 1 in 35,000 histologically identified BCCs [74]. There is a paucity of literature investigating mutations associated with metastasis, but in a small sample of eight patients, all eight patients had identical genetic mutations in both the primary tumor and metastatic site [75]. A wide variation of mutations were identified, but four of the eight patients had SMO mutations in the primary tumor or metastasis, known to provide resistance to vismodegib [75]. Greater research is needed to understand the pathogenesis of metastatic BCC.

\section{Conclusions}

The molecular basis of BCC is complex, involving an interplay of inherited genetic susceptibility and somatic mutations contributing to tumor development. Recent advances in sequencing have allowed us to better explore mutational drivers and implicated molecular pathways. The emerging therapies that we have discussed are based on these insights gained over the past decade into the molecular pathogenesis of BCC, reflecting the importance of this work. As our understanding continues to increase, we look forward to exciting, paradigm-shifting, innovation in the management of humankind's most common cancer.

Author Contributions: J.M.K. and K.Y.S. conceived of this work. J.M.K., J.L.J. and K.Y.S. wrote and revised the manuscript. All authors have read and agreed to the published version of the manuscript.

Funding: This article received no external funding.

Conflicts of Interest: The authors declare no conflict of interest.

\section{References}

1. Lomas, A.; Leonardi-Bee, J.; Bath-Hextall, F. A Systematic Review of Worldwide Incidence of Nonmelanoma Skin Cancer. Br. J. Dermatol. 2012, 166, 1069-1080. [CrossRef]

2. Miller, D.L.; Weinstock, M.A. Nonmelanoma Skin Cancer in the United States: Incidence. J. Am. Acad. Dermatol. 1994, 30, 774-778. [CrossRef]

3. Epstein, E.H. Basal Cell Carcinomas: Attack of the Hedgehog. Nat. Rev. Cancer 2008, 8, 743-754. [CrossRef]

4. Guy, G.P.; Machlin, S.R.; Ekwueme, D.U.; Yabroff, K.R. Prevalence and Costs of Skin Cancer Treatment in the U.S., 2002-2006 and 2007-2011. Am. J. Prev. Med. 2015, 48, 183-187. [CrossRef]

5. Rogers, H.W.; Weinstock, M.A.; Feldman, S.R.; Coldiron, B.M. Incidence Estimate of Nonmelanoma Skin Cancer (Keratinocyte Carcinomas) in the US Population, 2012. JAMA Derm. 2015, 151, 1081-1086. [CrossRef] [PubMed]

6. Choquet, H.; Ashrafzadeh, S.; Kim, Y.; Asgari, M.M.; Jorgenson, E. Genetic and Environmental Factors Underlying Keratinocyte Carcinoma Risk. JCI Insight 2020, 5, 134783. [CrossRef]

7. Pellegrini, C.; Maturo, M.G.; Di Nardo, L.; Ciciarelli, V.; Gutiérrez García-Rodrigo, C.; Fargnoli, M.C. Understanding the Molecular Genetics of Basal Cell Carcinoma. Int. J. Mol. Sci. 2017, 18, 2485. [CrossRef]

8. Mucci, L.A.; Hjelmborg, J.B.; Harris, J.R.; Czene, K.; Havelick, D.J.; Scheike, T.; Graff, R.E.; Holst, K.; Möller, S.; Unger, R.H.; et al. Familial Risk and Heritability of Cancer Among Twins in Nordic Countries. JAMA 2016, 315, 68-76. [CrossRef] [PubMed]

9. Ge, T.; Chen, C.-Y.; Neale, B.M.; Sabuncu, M.R.; Smoller, J.W. Phenome-Wide Heritability Analysis of the UK Biobank. PLoS Genet. 2017, 13, e1006711. [CrossRef]

10. Evans, D.G.; Howard, E.; Giblin, C.; Clancy, T.; Spencer, H.; Huson, S.M.; Lalloo, F. Birth Incidence and Prevalence of Tumor-Prone Syndromes: Estimates from a UK Family Genetic Register Service. Am. J. Med. Genet. A 2010, 152, 327-332. [CrossRef] 
11. Anderson, D.E.; Taylor, W.B.; Falls, H.F.; Davidson, R.T. The Nevoid Basal Cell Carcinoma Syndrome. Am. J. Hum. Genet. 1967, $19,12-22$.

12. Jones, E.A.; Sajid, M.I.; Shenton, A.; Evans, D.G. Basal Cell Carcinomas in Gorlin Syndrome: A Review of 202 Patients. J. Skin Cancer 2011, 2011, 217378. [CrossRef] [PubMed]

13. Yasar, B.; Byers, H.J.; Smith, M.J.; Lear, J.; Oudit, D.; Bholah, Z.; Roberts, S.A.; Newman, W.G.; Evans, D.G. Common Variants Modify the Age of Onset for Basal Cell Carcinomas in Gorlin Syndrome. Eur. J. Hum. Genet. 2015, 23, 708-710. [CrossRef]

14. Kimonis, V.E.; Goldstein, A.M.; Pastakia, B.; Yang, M.L.; Kase, R.; DiGiovanna, J.J.; Bale, A.E.; Bale, S.J. Clinical Manifestations in 105 Persons with Nevoid Basal Cell Carcinoma Syndrome. Am. J. Med. Genet. 1997, 69, 299-308. [CrossRef]

15. Evans, D.G.; Oudit, D.; Smith, M.J.; Rutkowski, D.; Allan, E.; Newman, W.G.; Lear, J.T. First Evidence of Genotype-Phenotype Correlations in Gorlin Syndrome. J. Med. Genet. 2017, 54, 530-536. [CrossRef]

16. Farndon, P.A.; Del Mastro, R.G.; Evans, D.G.; Kilpatrick, M.W. Location of Gene for Gorlin Syndrome. Lancet 1992, 339, 581-582. [CrossRef]

17. Lam, C.-W.; Leung, C.-Y.; Lee, K.-C.; Xie, J.; Lo, F.-M.; Au, T.-S.; Tong, S.-F.; Poon, M.-K.; Chan, L.-Y.; Luk, N.-M. Novel Mutations in the PATCHED Gene in Basal Cell Nevus Syndrome. Mol. Genet. Metab. 2002, 76, 57-61. [CrossRef]

18. Lo Muzio, L. Nevoid Basal Cell Carcinoma Syndrome (Gorlin Syndrome). Orphanet J. Rare Dis. 2008, 3, 32. [CrossRef]

19. i Altaba, A.R.; Sánchez, P.; Dahmane, N. Gli and Hedgehog in Cancer: Tumours, Embryos and Stem Cells. Nat. Rev. Cancer 2002, 2,361-372. [CrossRef]

20. Dahmane, N.; Lee, J.; Robins, P.; Heller, P.; i Altaba, A.R. Activation of the Transcription Factor Gli1 and the Sonic Hedgehog Signalling Pathway in Skin Tumours. Nature 1997, 389, 876-881. [CrossRef]

21. Booth, D.R. The Hedgehog Signalling Pathway and Its Role in Basal Cell Carcinoma. Cancer Metastasis Rev. 1999, 18, 261-284. [CrossRef] [PubMed]

22. Torrelo, A.; Sprecher, E.; Mediero, I.G.; Bergman, R.; Zambrano, A. What Syndrome Is This? Bazex-Dupre-Christol Syndrome. Pediatr. Dermatol. 2006, 23, 286-290. [CrossRef]

23. Bal, E.; Park, H.-S.; Belaid-Choucair, Z.; Kayserili, H.; Naville, M.; Madrange, M.; Chiticariu, E.; Hadj-Rabia, S.; Cagnard, N.; Kuonen, F.; et al. Mutations in ACTRT1 and Its Enhancer RNA Elements Lead to Aberrant Activation of Hedgehog Signaling in Inherited and Sporadic Basal Cell Carcinomas. Nat. Med. 2017, 23, 1226-1233. [CrossRef]

24. DiGiovanna, J.J.; Kraemer, K.H. Shining a Light on Xeroderma Pigmentosum. J. Investig. Dermatol. 2012, 132, 785-796. [CrossRef]

25. Black, J.O. Xeroderma Pigmentosum. Head Neck Pathol. 2016, 10, 139-144. [CrossRef]

26. van Dam, R.M.; Huang, Z.; Rimm, E.B.; Weinstock, M.A.; Spiegelman, D.; Colditz, G.A.; Willett, W.C.; Giovannucci, E. Risk Factors for Basal Cell Carcinoma of the Skin in Men: Results from the Health Professionals Follow-up Study. Am. J. Epidemiol. 1999, 150, 459-468. [CrossRef]

27. Zanetti, R.; Rosso, S.; Martinez, C.; Nieto, A.; Miranda, A.; Mercier, M.; Loria, D.I.; Østerlind, A.; Greinert, R.; Navarro, C.; et al. Comparison of Risk Patterns in Carcinoma and Melanoma of the Skin in Men: A Multi-Centre Case-Case-Control Study. Br. J. Cancer 2006, 94, 743-751. [CrossRef]

28. Khalesi, M.; Whiteman, D.C.; Tran, B.; Kimlin, M.G.; Olsen, C.M.; Neale, R.E. A Meta-Analysis of Pigmentary Characteristics, Sun Sensitivity, Freckling and Melanocytic Nevi and Risk of Basal Cell Carcinoma of the Skin. Cancer Epidemiol. 2013, 37, 534-543. [CrossRef]

29. Chahal, H.S.; Wu, W.; Ransohoff, K.J.; Yang, L.; Hedlin, H.; Desai, M.; Lin, Y.; Dai, H.-J.; Qureshi, A.A.; Li, W.-Q.; et al. Genome-Wide Association Study Identifies 14 Novel Risk Alleles Associated with Basal Cell Carcinoma. Nat. Commun. 2016, 7. [CrossRef]

30. Nan, H.; Xu, M.; Kraft, P.; Qureshi, A.A.; Chen, C.; Guo, Q.; Hu, F.B.; Curhan, G.; Amos, C.I.; Wang, L.-E.; et al. GenomeWide Association Study Identifies Novel Alleles Associated with Risk of Cutaneous Basal Cell Carcinoma and Squamous Cell Carcinoma. Hum. Mol. Genet. 2011, 20, 3718-3724. [CrossRef]

31. Stacey, S.N.; Gudbjartsson, D.F.; Sulem, P.; Bergthorsson, J.T.; Kumar, R.; Thorleifsson, G.; Sigurdsson, A.; Jakobsdottir, M.; Sigurgeirsson, B.; Benediktsdottir, K.R.; et al. Common Variants on 1p36 and 1q42 Are Associated with Cutaneous Basal Cell Carcinoma but Not with Melanoma or Pigmentation Traits. Nat. Genet. 2008, 40, 1313-1318. [CrossRef]

32. Stacey, S.N.; Helgason, H.; Gudjonsson, S.A.; Thorleifsson, G.; Zink, F.; Sigurdsson, A.; Kehr, B.; Gudmundsson, J.; Sulem, P.; Sigurgeirsson, B.; et al. New Basal Cell Carcinoma Susceptibility Loci. Nat. Commun. 2015, 6, 6825. [CrossRef]

33. Rafnar, T.; Sulem, P.; Stacey, S.N.; Geller, F.; Gudmundsson, J.; Sigurdsson, A.; Jakobsdottir, M.; Helgadottir, H.; Thorlacius, S.; Aben, K.K.H.; et al. Sequence Variants at the TERT-CLPTM1L Locus Associate with Many Cancer Types. Nat. Genet. 2009, 41, 221-227. [CrossRef] [PubMed]

34. Stacey, S.N.; Sulem, P.; Gudbjartsson, D.F.; Jonasdottir, A.; Thorleifsson, G.; Gudjonsson, S.A.; Masson, G.; Gudmundsson, J.; Sigurgeirsson, B.; Benediktsdottir, K.R.; et al. Germline Sequence Variants in TGM3 and RGS22 Confer Risk of Basal Cell Carcinoma. Hum. Mol. Genet. 2014, 23, 3045-3053. [CrossRef] [PubMed]

35. Stacey, S.N.; Sulem, P.; Jonasdottir, A.; Masson, G.; Gudmundsson, J.; Gudbjartsson, D.F.; Magnusson, O.T.; Gudjonsson, S.A.; Sigurgeirsson, B.; Thorisdottir, K.; et al. A Germline Variant in the TP53 Polyadenylation Signal Confers Cancer Susceptibility. Nat. Genet. 2011, 43, 1098-1103. [CrossRef] 
36. Stacey, S.N.; Sulem, P.; Masson, G.; Gudjonsson, S.A.; Thorleifsson, G.; Jakobsdottir, M.; Sigurdsson, A.; Gudbjartsson, D.F.; Sigurgeirsson, B.; Benediktsdottir, K.R.; et al. New Common Variants Affecting Susceptibility to Basal Cell Carcinoma. Nat. Genet. 2009, 41, 909-914. [CrossRef]

37. Han, J.; Kraft, P.; Colditz, G.A.; Wong, J.; Hunter, D.J. Melanocortin 1 Receptor Variants and Skin Cancer Risk. Int. J. Cancer 2006, 119, 1976-1984. [CrossRef]

38. Box, N.F.; Duffy, D.L.; Irving, R.E.; Russell, A.; Chen, W.; Griffyths, L.R.; Parsons, P.G.; Green, A.C.; Sturm, R.A. Melanocortin-1 Receptor Genotype Is a Risk Factor for Basal and Squamous Cell Carcinoma. J. Investig. Dermatol. 2001, 116, 224-229. [CrossRef]

39. Gudbjartsson, D.F.; Sulem, P.; Stacey, S.N.; Goldstein, A.M.; Rafnar, T.; Sigurgeirsson, B.; Benediktsdottir, K.R.; Thorisdottir, K.; Ragnarsson, R.; Sveinsdottir, S.G.; et al. ASIP and TYR Pigmentation Variants Associate with Cutaneous Melanoma and Basal Cell Carcinoma. Nat. Genet. 2008, 40, 886-891. [CrossRef]

40. Bogenrieder, T.; Herlyn, M. The Molecular Pathology of Cutaneous Melanoma. Cancer Biomark. 2010, 9, 267-286. [CrossRef]

41. Nowell, C.; Radtke, F. Cutaneous Notch Signaling in Health and Disease. Cold Spring Harb. Perspect. Med. 2013,3 , a017772. [CrossRef]

42. Shi, F.-T.; Yu, M.; Zloty, D.; Bell, R.H.; Wang, E.; Akhoundsadegh, N.; Leung, G.; Haegert, A.; Carr, N.; Shapiro, J.; et al. Notch Signaling Is Significantly Suppressed in Basal Cell Carcinomas and Activation Induces Basal Cell Carcinoma Cell Apoptosis. Mol. Med. Rep. 2017, 15, 1441-1454. [CrossRef]

43. Vargas-Rondón, N.; Villegas, V.E.; Rondón-Lagos, M. The Role of Chromosomal Instability in Cancer and Therapeutic Responses. Cancers 2017, 10, 4. [CrossRef]

44. Reddy, B.Y.; Miller, D.M.; Tsao, H. Somatic Driver Mutations in Melanoma. Cancer 2017, 123, 2104-2117. [CrossRef]

45. Lin, Y.; Chahal, H.S.; Wu, W.; Cho, H.G.; Ransohoff, K.J.; Song, F.; Tang, J.Y.; Sarin, K.Y.; Han, J. Association Study of Genetic Variation in DNA Repair Pathway Genes and Risk of Basal Cell Carcinoma. Int. J. Cancer 2017, 141, 952-957. [CrossRef] [PubMed]

46. Welsh, M.M.; Applebaum, K.M.; Spencer, S.K.; Perry, A.E.; Karagas, M.R.; Nelson, H.H. CTLA4 Variants, UV-Induced Tolerance, and Risk of Non-Melanoma Skin Cancer. Cancer Res. 2009, 69, 6158-6163. [CrossRef]

47. Ramachandran, S.; Fryer, A.A.; Smith, A.; Lear, J.; Bowers, B.; Jones, P.W.; Strange, R.C. Cutaneous Basal Cell Carcinomas: Distinct Host Factors Are Associated with the Development of Tumors on the Trunk and on the Head and Neck. Cancer 2001, 92, 354-358. [CrossRef]

48. Ramachandran, S.; Lear, J.T.; Ramsay, H.; Smith, A.G.; Bowers, B.; Hutchinson, P.E.; Jones, P.W.; Fryer, A.A.; Strange, R.C. Presentation with Multiple Cutaneous Basal Cell Carcinomas: Association of Glutathione S-Transferase and Cytochrome P450 Genotypes with Clinical Phenotype. Cancer Epidemiol. Biomark. Prev. 1999, 8, 61-67.

49. Yengi, L.; Inskip, A.; Gilford, J.; Alldersea, J.; Bailey, L.; Smith, A.; Lear, J.T.; Heagerty, A.H.; Bowers, B.; Hand, P.; et al. Polymorphism at the Glutathione S-Transferase Locus GSTM3: Interactions with Cytochrome P450 and Glutathione S-Transferase Genotypes as Risk Factors for Multiple Cutaneous Basal Cell Carcinoma. Cancer Res. 1996, 56, 1974-1977. [PubMed]

50. Ramachandran, S.; Fryer, A.A.; Lovatt, T.J.; Smith, A.G.; Lear, J.T.; Jones, P.W.; Strange, R.C. Combined Effects of Gender, Skin Type and Polymorphic Genes on Clinical Phenotype: Use of Rate of Increase in Numbers of Basal Cell Carcinomas as a Model System. Cancer Lett. 2003, 189, 175-181. [CrossRef]

51. Hajeer, A.H.; Lear, J.T.; Ollier, W.E.; Naves, M.; Worthington, J.; Bell, D.A.; Smith, A.G.; Bowers, W.P.; Jones, P.W.; Strange, R.C.; et al. Preliminary Evidence of an Association of Tumour Necrosis Factor Microsatellites with Increased Risk of Multiple Basal Cell Carcinomas. Br. J. Dermatol. 2000, 142, 441-445. [CrossRef]

52. Bonilla, X.; Parmentier, L.; King, B.; Bezrukov, F.; Kaya, G.; Zoete, V.; Seplyarskiy, V.B.; Sharpe, H.J.; McKee, T.; Letourneau, A.; et al. Genomic Analysis Identifies New Drivers and Progression Pathways in Skin Basal Cell Carcinoma. Nat. Genet. 2016, 48, 398-406. [CrossRef]

53. Jayaraman, S.S.; Rayhan, D.J.; Hazany, S.; Kolodney, M.S. Mutational Landscape of Basal Cell Carcinomas by Whole-Exome Sequencing. J. Investig. Dermatol. 2014, 134, 213-220. [CrossRef]

54. Seebode, C.; Lehmann, J.; Emmert, S. Photocarcinogenesis and Skin Cancer Prevention Strategies. Anticancer Res. 2016, 36, 1371-1378. [PubMed]

55. Hatton, B.A.; Knoepfler, P.S.; Kenney, A.M.; Rowitch, D.H.; de Alborán, I.M.; Olson, J.M.; Eisenman, R.N. N-Myc Is an Essential Downstream Effector of Shh Signaling during Both Normal and Neoplastic Cerebellar Growth. Cancer Res. 2006, 66, 8655-8661. [CrossRef]

56. Giglia-Mari, G.; Sarasin, A. TP53 Mutations in Human Skin Cancers. Hum. Mutat. 2003, 21, 217-228. [CrossRef]

57. Ziegler, A.; Leffell, D.J.; Kunala, S.; Sharma, H.W.; Gailani, M.; Simon, J.A.; Halperin, A.J.; Baden, H.P.; Shapiro, P.E.; Bale, A.E. Mutation Hotspots Due to Sunlight in the P53 Gene of Nonmelanoma Skin Cancers. Proc. Natl. Acad. Sci. USA 1993, 90, 4216-4220. [CrossRef]

58. Schlegelmilch, K.; Mohseni, M.; Kirak, O.; Pruszak, J.; Rodriguez, J.R.; Zhou, D.; Kreger, B.T.; Vasioukhin, V.; Avruch, J.; Brummelkamp, T.R.; et al. Yap1 Acts Downstream of $\alpha$-Catenin to Control Epidermal Proliferation. Cell 2011, 144, 782-795. [CrossRef]

59. Welcker, M.; Orian, A.; Jin, J.; Grim, J.E.; Grim, J.A.; Harper, J.W.; Eisenman, R.N.; Clurman, B.E. The Fbw7 Tumor Suppressor Regulates Glycogen Synthase Kinase 3 Phosphorylation-Dependent c-Myc Protein Degradation. Proc. Natl. Acad. Sci. USA 2004, 101, 9085-9090. [CrossRef] [PubMed] 
60. Denisova, E.; Heidenreich, B.; Nagore, E.; Rachakonda, P.S.; Hosen, I.; Akrap, I.; Traves, V.; García-Casado, Z.; López-Guerrero, J.A.; Requena, C.; et al. Frequent DPH3 Promoter Mutations in Skin Cancers. Oncotarget 2015, 6, 35922-35930. [CrossRef]

61. Wang, L.; Shi, Y.; Ju, P.; Liu, R.; Yeo, S.P.; Xia, Y.; Owlanj, H.; Feng, Z. Silencing of Diphthamide Synthesis 3 (Dph3) Reduces Metastasis of Murine Melanoma. PLoS ONE 2012, 7, e49988. [CrossRef]

62. Campione, E.; Di Prete, M.; Lozzi, F.; Lanna, C.; Spallone, G.; Mazzeo, M.; Cosio, T.; Rapanotti, C.; Dika, E.; Gaziano, R.; et al. High-Risk Recurrence Basal Cell Carcinoma: Focus on Hedgehog Pathway Inhibitors and Review of the Literature. Chemotherapy 2020, 65, 2-10. [CrossRef] [PubMed]

63. Rimkus, T.K.; Carpenter, R.L.; Qasem, S.; Chan, M.; Lo, H.-W. Targeting the Sonic Hedgehog Signaling Pathway: Review of Smoothened and GLI Inhibitors. Cancers 2016, 8, 22. [CrossRef] [PubMed]

64. Basset-Séguin, N.; Hauschild, A.; Kunstfeld, R.; Grob, J.; Dréno, B.; Mortier, L.; Ascierto, P.A.; Licitra, L.; Dutriaux, C.; Thomas, L.; et al. Vismodegib in Patients with Advanced Basal Cell Carcinoma: Primary Analysis of STEVIE, an International, Open-Label Trial. Eur. J. Cancer 2017, 86, 334-348. [CrossRef] [PubMed]

65. Lear, J.T.; Migden, M.R.; Lewis, K.D.; Chang, A.L.S.; Guminski, A.; Gutzmer, R.; Dirix, L.; Combemale, P.; Stratigos, A.; Plummer, R.; et al. Long-Term Efficacy and Safety of Sonidegib in Patients with Locally Advanced and Metastatic Basal Cell Carcinoma: 30-Month Analysis of the Randomized Phase 2 BOLT Study. J. Eur. Acad. Dermatol. Venereol. 2018, 32, $372-381$. [CrossRef]

66. Epstein, E.H.; Lear, J.; Saldanha, G.; Tang, J.Y.; Harwood, C. Hedgehog Pathway Inhibition by Topical Patidegib to Reduce BCC Burden in Patients with Basal Cell Nevus (Gorlin) Syndrome. J. Clin. Oncol. 2018, 36, e21626. [CrossRef]

67. Sohn, G.K.; Kwon, G.P.; Bailey-Healy, I.; Mirza, A.; Sarin, K.; Oro, A.; Tang, J.Y. Topical Itraconazole for the Treatment of Basal Cell Carcinoma in Patients With Basal Cell Nevus Syndrome or High-Frequency Basal Cell Carcinomas: A Phase 2, Open-Label, Placebo-Controlled Trial. JAMA Dermatol. 2019, 155, 1078-1080. [CrossRef] [PubMed]

68. Lipson, E.J.; Lilo, M.T.; Ogurtsova, A.; Esandrio, J.; Xu, H.; Brothers, P.; Schollenberger, M.; Sharfman, W.H.; Taube, J.M. Basal Cell Carcinoma: PD-L1/PD-1 Checkpoint Expression and Tumor Regression after PD-1 Blockade. J. Immunother. Cancer $2017,5,23$. [CrossRef]

69. Stratigos, A.J.; Sekulic, A.; Peris, K.; Bechter, O.; Prey, S.; Kaatz, M.; Lewis, K.D.; Basset-Seguin, N.; Chang, A.L.S.; Dalle, S.; et al. Cemiplimab in Locally Advanced Basal Cell Carcinoma after Hedgehog Inhibitor Therapy: An Open-Label, Multi-Centre, Single-Arm, Phase 2 Trial. Lancet Oncol. 2021, 22, 848-857. [CrossRef]

70. Chang, A.L.S.; Tran, D.C.; Cannon, J.G.D.; Li, S.; Jeng, M.; Patel, R.; van der Bokke, L.; Pague, A.; Brotherton, R.; Rieger, K.E.; et al. Pembrolizumab for Advanced Basal Cell Carcinoma: An Investigator-Initiated, Proof-of-Concept Study. J. Am. Acad. Dermatol. 2019, 80, 564-566. [CrossRef]

71. Cho, E.-A.; Moloney, F.J.; Cai, H.; Au-Yeung, A.; China, C.; Scolyer, R.A.; Yosufi, B.; Raftery, M.J.; Deng, J.Z.; Morton, S.W.; et al. Safety and Tolerability of an Intratumorally Injected DNAzyme, Dz13, in Patients with Nodular Basal-Cell Carcinoma: A Phase 1 First-in-Human Trial (DISCOVER). Lancet 2013, 381, 1835-1843. [CrossRef]

72. Mirza, A.N.; Fry, M.A.; Urman, N.M.; Atwood, S.X.; Roffey, J.; Ott, G.R.; Chen, B.; Lee, A.; Brown, A.S.; Aasi, S.Z.; et al. Combined Inhibition of Atypical PKC and Histone Deacetylase 1 Is Cooperative in Basal Cell Carcinoma Treatment. JCI Insight 2017, $2,97071$. [CrossRef]

73. Mirza, A.N.; McKellar, S.A.; Urman, N.M.; Brown, A.S.; Hollmig, T.; Aasi, S.Z.; Oro, A.E. LAP2 Proteins Chaperone GLI1 Movement between the Lamina and Chromatin to Regulate Transcription. Cell 2019, 176, 198-212.e15. [CrossRef] [PubMed]

74. von Domarus, H.; Stevens, P.J. Metastatic Basal Cell Carcinoma. Report of Five Cases and Review of 170 Cases in the Literature. J. Am. Acad. Dermatol. 1984, 10, 1043-1060. [CrossRef]

75. Verkouteren, B.J.A.; Wakkee, M.; van Geel, M.; van Doorn, R.; Winnepenninckx, V.J.; Korpershoek, E.; Mooyaart, A.L.; Reyners, A.K.L.; Terra, J.B.; Aarts, M.J.B.; et al. Molecular Testing in Metastatic Basal Cell Carcinoma. J. Am. Acad. Dermatol. 2019. [CrossRef] 